\title{
The relationship between pre-mir-146a G/C polymorphism and risk of gastric cancer in patients with gastric cancer in Ardabil province, Iran
}

\author{
Moradpour Hesari $\mathbf{R}^{1}$, Damandan $\mathbf{M}^{\mathbf{1}}$, Hosseini-Asl $\mathbf{S}^{2} *$
}

${ }^{1}$ Genetics graduate student at Islamic Azad University of Ahar, Iran

${ }^{2}$ Assistant Professor of Medical Sciences Ardabil University, Iran

Received: 07 June 2015

Accepted: 20 June 2015

\section{*Correspondence:}

S Saied Hosseini-Asl,

E-mail: hosseiniasl@gmail.ac.ir

Copyright: ( $)$ the author(s), publisher and licensee Medip Academy. This is an open-access article distributed under the terms of the Creative Commons Attribution Non-Commercial License, which permits unrestricted non-commercial use, distribution, and reproduction in any medium, provided the original work is properly cited.

\begin{abstract}
Background: MicroRNAs (miRNAs) are endogenous non-protein-coding short RNAs of 21-23 nucleotides (Kim, 2005; Bartel, 2004).polymorphism in human pre-mir-146a has been recently implicated in human cancers. Gastric cancer (GC) is the most of common cancers, and is especially common in Ardabil province, located in North-West Iran. Single nucleotide polymorphism (SNP)is the most common type of genetic variation in the human genome .polymorphisms in human pre-mi RNA genome lesion modify the processing and/or target selection of human mi RNAs, which are implicated in cell cycle regulation, and thereby play critical roles in carcinogenesis. Pre-mir-146a $\mathrm{G} / \mathrm{C}$ polymorphism designated rs 2910164 is located on chromosome 5 , in the stem region opposite to the mature premir-146a sequence.

Methods: We performed a hospital-based, case-control study using polymerase chain reaction-restriction fragment length polymorphism (PCR-RFLP) method in 100 individuals (50 gastric cancer patients and 50 age and sex matched cancer - free controls). The frequency of genotypes was $9(18 \%), 17(34 \%)$, and $24(48 \%)$ among cases and 3(6\%), $14(28 \%)$, and $33(66 \%)$ among controls for $\mathrm{C} / \mathrm{C}, \mathrm{G} / \mathrm{C}$, and $\mathrm{G} / \mathrm{G}$, respectively. The 147bp amplified fragment was digested by Sac1 (Thermo science co.). An uncut fragment indicates allele G. However, substitution of $\mathrm{C}$ allele by $\mathrm{G}$ allele tends to create a Sac1 restriction site. Therefore, $\mathrm{C}$ allele is observed by $122 \mathrm{bp}$ and $25 \mathrm{bp}$ digested products. If the quantity of restriction enzyme used is inadequate, the homozygous may be detected as heterozygote, therefore, some sequenced samples were chosen for evaluating the accuracy of digestion. All the statistical analyses were performed using spss software.

Results: The frequencies of pre-miR-146a G/C genotypes in the case groups were significantly different from those in the control groups although clinically CC genotype in patients with gastric cancer incidence was higher than the control groups $(18 \%$ versus $6 \%)$, so this difference was statistically significant $(\mathrm{p}=0.038)$.

Conclusions: In this study, between the polymorphism of G/C hsa-mir-146a and the risk of gastric cancer in Ardabil province, a significant relationship was found.
\end{abstract}

Keywords: Gastric cancer, Pre-mir-146a, Polymorphism, Ardabil

\section{INTRODUCTION}

MicroRNAs (mi RNAs) are endogenous non-proteincoding short RNAs of 18 - 25 nucleotides RNAs, have a focus on this stage researches. They are encoded in the genome and are generally transcribed by RNA polymerase II, and exert their effects by associating with a group of proteins termed the 'RNA-induced silencing complex' (RISC). RISC is directed to target mRNAs via imperfect sequence complementarity between the mi RNA and $3^{\prime}$ 'translated region (3'-UTR) of target mRNAs. In almost all studied examples, the targeting of a transcript by RISC leads to down-regulated gene expression through mRNA cleavage or translation 
inhibition. ${ }^{1}$ mi RNAs have been shown to play crucial roles in diverse biological processes, such as cell apoptosis, differentiation, development, signal transduction. $^{2-3}$ Watson-Crick complementarity between the target and the seed region (2-8 nucleotides) of the mature mi RNA is both necessary and sufficient for targeting and regulating of mRNAs by mi RNAs. But the seed region of mi RNAs is so short, so its polymorphism may affect the combination of the core area of binding the 3 'UTR of target genes, thus affecting its regulation of target genes. ${ }^{4}$ A Homo sapiens miR-146a gene located on chromosome, it has been reported that it play a vital role in several human cancers. Recently, single nucleotide polymorphism (SNP, rs2910164) has been identified in the miR-146a gene. More recently, Several studies have assessed the relationship between the polymorphism of miR-146a $\mathrm{G}>\mathrm{C}$ and the risks to digestive cancers, however, the results have been controversial. ${ }^{5-10}$ To derive a more precise effect on the association between miR-146a polymorphism and digestive cancers risks Therefore, we conducted this meta-analysis. Gastric cancer (GC) is the most of common cancers, and is especially common in Ardabil province of North-West Iran, there is wide variation in gastric cancer incidence among various areas, Ardabil province has been reported to have the highest incidence rate in the country. Gastric cancer is the second leading cause of cancer-related death in the world. ${ }^{11}$ currently; it remains one of common cancer types and still is a leading cause of cancer-related death. The development and progression of gastric cancer have been characterized by multiple genetic mutations of proto-oncogenes and tumor-suppressor genes. ${ }^{12-13}$ Because of the interaction between genetic and environmental factors and diversities present in different environment, the importance of genetic variations on caner susceptibility could vary among different populations. Replacement, $\mathrm{C}$ allele by $\mathrm{G}$ allele tends to create an enzyme restriction site. The present report describes a case-control study aimed to assay the effect of pre-mir-146a G/C polymorphism on gastric cancer susceptibility in Ardabil province, Iran.

\section{METHODS}

\section{Samples}

We performed a hospital-based, case-control study using polymerase chain reaction-restriction fragment length polymorphism (PCR-RFLP) method in 100 individuals (50 gastric cancer patients and 50 age and sex matched cancer - free controls). All cases were newly diagnosed and histopathologically confirmed gastric cancer. The case population was diagnosed with primary incident gastric cancer and the secondary recurrent tumors were excluded. Control subjects had no current or previous diagnosis of cancer were frequency matched to cases on age and gender all subjects were interviewed using a structured questionnaire to obtain information on demographic data including age, gender. A tumor location was obtained from histopathology record of the gastric cancer patients. After the interview approximately $5 \mathrm{ml}$ of venous blood sample was collect with a coded tube from each subject.

\section{Genotyping}

Genomic DNA was isolated from $200 \mathrm{ml}$ of whole blood adding the blood genome DNA extraction kit (Manual Archive pure DNA Purification) and stored at $-20 \dot{\mathrm{C}}$. The mir146a polymorphism was determined using the method polymerase chain reaction (PCR) restriction fragment length polymorphism (RFLP). The following primers: 5' - CATGGGTTGTGTCAGTGTCAGAGCT3', 5' - TGCCTTCTGTCTCCAGTCTTCCAA- 3'. briefly, $20 \mu \mathrm{l}$ PCR mixture containing 300ng genomic DNA with, $0.25 \mu \mathrm{M}$ of both primers, $2 \mu \mathrm{l} 10 \mathrm{xPCR}$ buffer, $1.5 \mathrm{mM} \mathrm{Mgcl2}, 0.1 \mathrm{mM}$ dNTPs and 1U Tag DNA polymerase (Cinagene co.). The $147 \mathrm{bp}$ PCR product was digested by the restriction enzyme Sac1 (Thermo science co.). $5 \mathrm{U}$ at $37 \dot{\mathrm{C}}$ overnight, and then separated on a $3 \%$ agarose gel. Fragment size of 147 indicated the wild-type homozygous GG genotype, at fragment of 122 and $25 \mathrm{bp}$ for the variant homozygote $\mathrm{C}$ genotype. To ensure genotyping accuracy all analysis were performed blindly without knowledge of the case-control status. In addition, $10 \%$ of all samples were randomly selected and genotyping in duplicate and the result showed 100\% concordant.

\section{RESULTS}

\section{Study characteristics}

The mean age of the patient group was 66.5 years (range, 37-86 years), and there were no statistically significant differences in the distributions of age and gender between cases and controls. The mean age of controls was 62.1 years (range, 45-80 years). The characteristics of the participants are presented in Table 1.

Table 1: General characteristics of participants.

\begin{tabular}{|lll|}
\hline \multicolumn{1}{|l}{ Cases } & Controls(Age, Sex) \\
\hline No & 50 & 50 \\
\hline Age & $66.5 \pm 11.7$ & $62.1 \pm 8.4$ \\
\hline$\leq 50$ years & $7(14 \%)$ & $4(8 \%)$ \\
\hline$>50$ years & $43(86 \%)$ & $46(92 \%)$ \\
\hline Gender & & \\
\hline Female & $14(28 \%)$ & $18(36 \%)$ \\
\hline Male & $36(72 \%)$ & $32(64 \%)$ \\
\hline
\end{tabular}

Table 2 shows the distribution of $\mathrm{CC}$ genotype and its statistical relationships with $\mathrm{GC}, \mathrm{GG}, \mathrm{GG}+\mathrm{GC}$, and $\mathrm{CC}+\mathrm{GC}$ among the case and control groups. The distribution of this polymorphism in the control group was in Hardy-Weinberg equilibrium. The frequency of genotypes was $9(18 \%), 17(34 \%)$, and 24(48\%) among cases and 3(6\%), 14(28\%), and 33(66\%) among controls for $\mathrm{C} / \mathrm{C}, \mathrm{G} / \mathrm{C}$, and $\mathrm{G} / \mathrm{G}$, respectively. The $147 \mathrm{bp}$ 
amplified fragment was digested by Sac1 (Thermo science co.). An uncut fragment indicates allele G. However, substitution of $\mathrm{C}$ allele by $\mathrm{G}$ allele tends to create a Sac1 restriction site. Therefore, $\mathrm{C}$ allele is observed by $122 \mathrm{bp}$ and $25 \mathrm{bp}$ digested products. If the quantity of restriction enzyme used is inadequate, the homozygous may be detected as heterozygote, therefore, some sequenced samples were chosen for evaluating the accuracy of digestion. All the statistical analyses were performed using spss software. The frequencies of premiR-146a G/C genotypes in the case groups were significantly different from those in the control groups although clinically $\mathrm{CC}$ genotype in patients with gastric cancer incidence was higher than the control groups $(18 \%$ versus $6 \%$ ), so this difference was statistically significant $(\mathrm{p}=0.038)$. Although clinically $\mathrm{CC}$ genotype in patients with gastric cancer incidence was higher than the control groups $(18 \%$ versus 6\%), so this difference was statistically significant in Table 2 .

Table 2: Showing the causes of death.

\begin{tabular}{|lllll|} 
Genotypes & $\begin{array}{l}\text { Cases } \\
(\%)\end{array}$ & $\begin{array}{l}\text { Controls } \\
(\%)\end{array}$ & $\begin{array}{l}\text { Odds Ratio } \\
(\mathbf{9 5 \%} \text { CI) }\end{array}$ & $\begin{array}{l}\text { P } \\
\text { value }\end{array}$ \\
\hline CC & $9(18 \%)$ & $3(6 \%)$ & $0.24(0.06-0.09)$ & 0.038 \\
\hline GC & $17(34 \%)$ & $14(28 \%)$ & $0.6(0.2-1.4)$ & 0.25 \\
\hline CC+GC & $26(52 \%)$ & $17(34 \%)$ & $0.48(0.2-1.1)$ & 0.07 \\
\hline GG+GC & $41(82 \%)$ & $47(94 \%)$ & $0.83(0.4-1.6)$ & 0.6 \\
\hline GG(ref) & $24(48 \%)$ & $33(66 \%)$ & 1.00 & \\
\hline
\end{tabular}

\section{DISCUSSION}

MiRNAs are probable regulators of varieties of physiological and pathological processes. Some SNPs in pre-microRNAs, flanking regions or target sites have been demonstrated to affect certain physiological processes or related with diseases. ${ }^{12}$ Sometimes, single point mutations in the 7 mer seed sites of mi RNAs may reduce effectiveness or abolish Mir mediated repression may induce effectiveness or abolish Mir mediated repression. ${ }^{15}$ Some researchers have examined the association of miR-146a rs2910164 G > C polymorphism with several cancers risks, and a significant relationship was observed in several but not all studies. ${ }^{5-18}$ MicroRNAs involved in important biological processes related to differentiation, proliferation, apoptosis, angiogenesis and immune response. SNPs in mi RNAs can affect mi RNA function by modulating the transcription of the primary transcript, pri-mi RNA and pre- processing and maturation, or mi RNA-mRNA interactions, which could possibly contribute to cancer susceptibility. For miR-146a significant association of gastric cancer risk was found in overall analysis. Gastric cancer (GC) is the most of common cancers, and is especially common in Ardabil province of North-West Iran, there is wide variation in gastric cancer incidence among various areas, Ardabil province has been reported to have the highest incidence rate in the country. Gastric cancer is the second leading cause of cancer-related death in the world. ${ }^{11}$ The high incidence of gastric cancer in
Ardabil province, Iran, encouraged us to follow the predisposition and susceptibility factors, including gene polymorphisms. Replacement, $\mathrm{C}$ allele by $\mathrm{G}$ allele tends to create an enzyme restriction site. Gastric cancer is the 4th prevalent cancer around the world and second leading cause of death due to cancers. Ardabil province is one of the most prevalent areas of gastric cancers in Iran. It is well known that we divided RNA into protein-coding and non-coding RNA. Over the past decade, the field of RNA research has rapidly expanded. Many studies found that mRNA accounted for only $2 \%$ of all transcripts, and the remaining $98 \%$ are non-coding RNAs in the human genome, suggesting that the noncoding portion of the genome is of crucial importance in the development of normal tissue development and disease. A single gene may have multiple micro-RNA control, it must be understood so that the replacement of $\mathrm{C}$ instead of $\mathrm{G}$ in the sequence of mir-146a gastric cancer is the risk of candidate or not? The present report describes a casecontrol study aimed to assay the effect of pre-mir-146a G/C polymorphism on gastric cancer susceptibility in Ardabil province, Iran. The mir-146a polymorphism was one of the attractive assays. The G/C polymorphism results in a reduction in enzyme activity.

\section{ACKNOWLEDGEMENTS}

The result of this paper is from MSc thesis (Genetics graduate student) at Islamic Azad University of Ahar, Iran. Authors would like to thank Aras Gastrointestinal Research Center, Imam Hospital personnel for help.

Funding: No funding sources

Conflict of interest: None declared

Ethical approval: Not required

\section{REFERENCES}

1. Gregory RI, Yan KP, Amuthan G, Chendrimada T, Doratotaj B, Cooch N, Shiekhattar R. The Microprocessor complex mediates the genesis of microRNAs. 2004;432(7014):235-240.

2. Jazdzewski K, Liyanarachchi S, Swierniak M, Pachucki J, Ringel M. D, Jarzab B, de la Chappelle A. Polymorphic mature microRNAs from passenger strand of pre-miR-146a contribute to thyroid cancer Proc. Natl. Acad. Sci. USA, 2009;106:1502-1505.

3. DiCioccio R. A, Odunsi K, Lele S. B, Zhao H. a functional polymorphism in the miR-146a gene and age of familial breast/ovarian cancer diagnosis Carcinogenesis. 2008;29:1963-1966.

4. Hu J, Zacharek S, He Y. J, Lee H, Shumwa S, Duronio R. J, Xiong Y. WD40 protein FBW5 promotes ubiquitination of tumour suppressor TSC2 by DDB1-CUL4-ROC1 ligase. Genes Der. 2008;22(7): 866-871.

5. Xu T, Zhu Y, Wei Q. K, Yuan Y, Zhou F, Ge Y. Y, Yang J. R, Su H, Zhuang S. M. A functional polymorphism in the miR-146a gene is associated 
with the risk for hepatocellular carcinoma. Carcinogenesis, 2008;29:2126-2131.

6. Guo H, Wan K, Xiong G, Hu H, Wang D, Xu X, Guan X, Yang K, Bai Y. A functional variant in microRNA-146a is associated with risk of esophageal squamous cell carcinoma in Chinese Han Fam. Cancer, 2010;9:599-603.

7. Okubo M, Tahara T, Shibata T, Yamashita H, Nakamura M, Yoshioka D, Yonemura J, Ishizuka T, Arisawa $\mathrm{T}$ and Hirata I. Association between common genetic variants in pre-microRNAs and gastric cancer risk in Japanese population Helicobacter. 2010;15:524-531.

8. Zeng Y, Sun Q. M, Liu N. N, Dong G. H, Chen J, Yang L, Wang. Correlation between pre-miR-146a $\mathrm{C} / \mathrm{G}$ polymorphism and gastric cancer risk in Chinese population World J. Gastroenterol. 2010;16:3578-3583.

9. Akkiz H, Bayram S, Bekar A, Akgollu E, Uskudar O, Sandikci M. No association of pre-microRNA146a rs2910164 polymorphism and risk of hepatocellular carcinoma development in Turkish population: A case-control study.2011;486:104-109.

10. Hishida A, Matsuo K, Goto Y, Naito M, Wakai K, Tajima K, Hamajima N. Combined effect of miR146a rs2910164 G/C polymorphism and Toll-like receptor $4+3725 \mathrm{G} / \mathrm{C}$ polymorphism on the risk of severe gastric atrophy in Japanese Dig. Dis. Sci. 2011;56:1131-1137.

11. Kim J. H, Cho A, Yin H, Schafer D. A, Mouneimne G, Simpson K.J, Nguyen K. V, Brugge, J. S, Montell, D. J. Psidin, a conserved protein that regulates protrusion dynamics and cell migration. 2011;25(7):730-741.

12. Wu M.N, Joiner W. J, Dean, T, Yue Z, Smith C. J, Chen D, Hoshi T, Sehgal A, Koh K. SLEEPLESS, a Ly-6/neurotoxin family member regulates the levels, localization and activity of Shaker. Nat. Neurosci. 2010;13(1):69-75.
13. Wang J, Bi J, Liu X, Li K, Di J, Wang B. Hsa-miR146a polymorphism (rs2910164) and cancer risk: a meta-analysis of 19 case-control studies. Mol. Biol. Rep., 2012; 39:4571-4579.

14. Dong Wu, Fan Wang, Wei-Qi Dai, Lei He, Jie Lu, Ling $\mathrm{Xu}$, Chuan-Yong Guo. The miR-146a rs2910164 G > C Polymorphism and Susceptibility to Digestive Cancer in Chinese. Asian Pacific J Cancer Prev, 14 (1): 399-403.

15. Permuth-Wey J, Thompson R. C, Burton Nabors L, Olson J. J, Browning J. E, Madden M. H, Ann Chen Y, Egan K. M. A functional polymorphism in the pre-miR-146a gene is associated with risk and prognosis in adult glioma J. Neurooncol. 2011;105:639-646.

16. Catucci I, Yang R, Verderio P, Pizzamiglio S, Heesen L, Hemminki K, Sutter C, Wappenschmidt B, Dick M, et al. Evaluation of SNPs in miR-146a, miR196a2 and miR-499 as low-penetrance alleles in German and Italian familial breast cancer cases Hum. Mutat. 2010;31:E1052-1057.

17. Jazdzewski K, Murray E. L, Franssila K, Jarzab B, Schoenberg D. R. and de la Chapelle A. Common SNP in pre-miR-146a decreases mature Mir expression and predisposes to papillary thyroid carcinoma Proc. Natl. Acad. Sci. USA, 2008; 105:7269-7274.

18. Yue C, Wang M, Ding B, Wang W, Fu S, Zhou D, Zhang $\mathrm{Z}$ and Han S. Polymorphism of the pre-miR$146 \mathrm{a}$ is associated with risk of cervical cancer in a Chinese population .Gynecol. Oncol., 2011;122:337.

Cite this article as: Hesari MR, Damandan M, Hosseini AS. The relationship between pre-mir-146a $\mathrm{G} / \mathrm{C}$ polymorphism and risk of gastric cancer in patients with gastric cancer in Ardabil province, Iran. Int J Adv Med 2015;2:223-6. 